
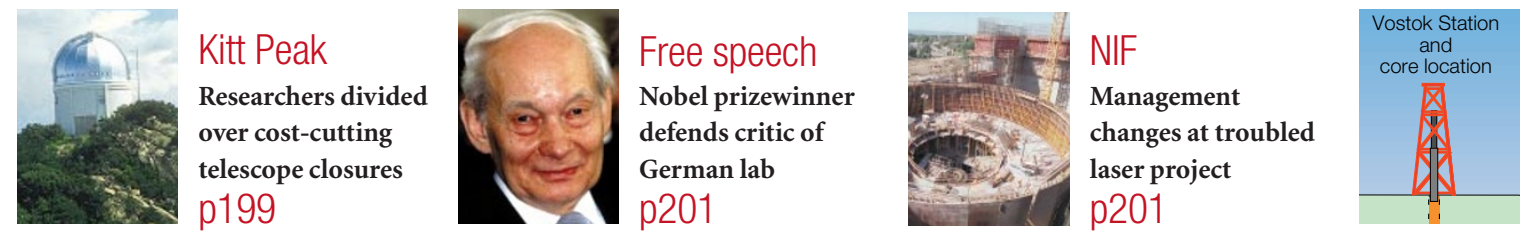

Lake Vostok

First contact with the surface for millions of years? p203

\title{
Staff accuse bosses of secrecy over British synchrotron plans...
}

London

Tensions are running high in Britain over whether its planned next-generation synchrotron source, Diamond, will be built at the Daresbury Laboratory, outside Manchester in the north of England, or at the Rutherford Appleton Laboratory (RAL), south of Oxford.

Scientific and technical staff at Daresbury, who operate the current UK Synchrotron Radiation Source and have worked on the $\mathfrak{E} 175$ million ( $\$ 280$ million) Diamond project for many years, say senior management has kept them in the dark over discussions about possibly siting the facility at the RAL.

Both sites are run by the Central Laboratory of the Research Councils (CLRC) - a third suggestion of a 'green field' site is said to have been ruled out. Diamond is a joint venture between the British government, the Wellcome Trust and France.

A decision in favour of the RAL would be a blow to Daresbury staff, whose union representatives last week met the science minister, David Sainsbury, to put the scientific and economic case for housing the new source near Manchester. Sainsbury has also heard from local members of parliament, trade unions and the regional development agency.

They say that losing Diamond would be an economic setback for the area, as Daresbury employs 500 of the region's 800 government scientists. Union representatives from both laboratories support Daresbury's bid and claim support from staff at both sites, expressing concern that, without Diamond, the CLRC might close Daresbury.

Local MP Mike Hall points out that Daresbury has been supported by the international user community. As the expertise to run Diamond is currently at Daresbury, he says, moving the machine elsewhere would mean relocating staff, and capital costs

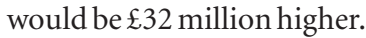

The CLRC is keen to distance itself from the lobbying. "It's not our remit," said a spokeswoman. "We've been providing scientific and financial information." She says that the CLRC has no preferred site.

But Daresbury staff complain that senior

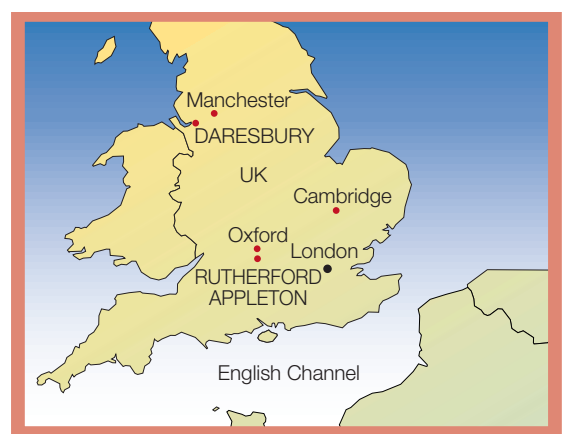

Moving south? Daresbury staff are surprised by the competition from the Rutherford Appleton.

CLRC staff have only recently allowed discussion over the site. Susan Smith, a union representative and scientist at Daresbury, says this separated Daresbury staff, as technical advisers, from senior CLRC management at the RAL, who were potential bidders. "We were told not to speak to anyone or contact anyone. Information from senior management to staff was stopped."

This has put Daresbury at a serious disadvantage, says Smith. When staff were told for the first time last month that the RAL was a contender, it came as "a complete shock".

It is unclear who is behind the move to site
Diamond at the RAL. Daresbury staff speak darkly of an "Oxford-Cambridge mafia", and there are rumours that the Wellcome Trust, which is providing most of the construction money (see Nature 394, 209; 1998), also favours this site.

Since announcing its contribution, the trust has discussed Diamond's site with the Office of Science and Technology (OST), and is said by some to prefer the Oxford location because it is closer to the UK's biomedical community in the south-east of England.

The trust, which declines to comment on the debate, has previously said that a decision on location would not be taken until potential users had been consulted "in collaboration with the research councils".

But little such consultation seems to have taken place. Mark Palmer, a member of the Medical Research Council's research management group, says the consultation on the use of Diamond by the biological sciences was intended to produce a technical report, and that the exercise "did not address location".

The Office of Science and Technology is said to have commissioned an independent site review. The decision on the site is expected to be announced in the next few weeks. Natasha Loder and Karen Birmingham

\section{... and French switch off in protest}

\section{Paris}

French scientists, angered at last month's government decision to scrap plans to build a new synchrotron in France and instead join with Britain to build a new machine there, have protested by refusing to restart two synchrotron machines after the summer vacation.

The researchers are continuing to challenge the financial basis of the government's decision and the argument that the future synchrotron needs of French scientists can be adequately met by using the UK-based machine and renting beamlines elsewhere in Europe.
In early August, Claude Allègre, the minister for national education, research and technology, announced that the French government would give FF350 million (US\$56 million) towards Diamond, a 3-GeV synchrotron, to be built in Britain (see Nature 400, 489; 1999 and above). This ended hopes that the government would construct a $2.15-\mathrm{GeV}$ source, Soleil, which had been in the planning stage since 1991 .

The move has incensed scientists and some French politicians, who have lobbied for eight years to build Soleil to replace two ageing facilities at LURE ( $800 \mathrm{MeV}$ and 1.85 $\mathrm{GeV}$ ), south of Paris. "We are responding to 
the minister, who, in making this decision, said that LURE doesn't serve a purpose," says Robert Comès, LURE's director. "If it doesn't serve a purpose, there's no reason to have it in use."

More than 300 scientists at LURE met last Monday and voted unanimously — with two abstentions - to leave the machines, which were shut down for August, turned off. Repeating their conviction that Soleil is essential for the future of French science, they agreed to refuse to collaborate in the Franco-British project, and demanded that Allègre reverse his decision.

However, Allègre, who has made European collaboration a cornerstone of his policy, shows no sign of relenting. According to Vincent Courtillot, director of research for the ministry, the government has been trying to trim costs on 'big science' facilities in order to inject more money into research at public laboratories.

"There is no doubt that synchrotron radiation is an important and necessary technique," says Courtillot. "The one thing we have been questioning is whether [Soleil] is really necessary, and whether we are prepared to give a large amount of money to it."

Courtillot admits that Diamond will fulfil only about one-third of French researchers' needs, but adds that the government is already negotiating to rent beamlines on BESSY II in Germany, SLS in Switzerland and Elettra in Italy.

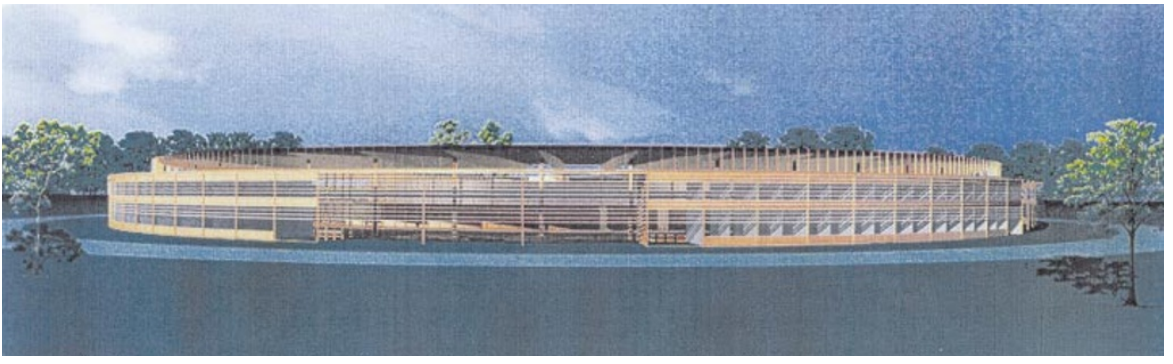

Eclipsed: plans for the Soleil synchrotron facility have been dropped by the French government.

"This should give us two-thirds of Soleil," Courtillot says. He adds that the government plans to join with Britain, France, Germany and Italy in coordinating the development and operation of large facilities, among them synchrotron radiation and neutron sources. This is expected to take up to four years to set up.

Several experts, however, have challenged the ministry's strategy, arguing that it could end up costing more than Soleil, while meeting a substantially smaller fraction of French research needs than Courtillot estimates. For example, researchers say that Diamond will meet one-quarter of their needs, not one-third.

Many question why Soleil is being abandoned for a European project if that project doesn't offer substantially greater benefits. "We have to look at what everything is going to cost, and what the advantages and disadvantages are," says one expert close to the project. "The debate has been very passionate, but there has been no rational discussion.”

Soleil, projected to cost FF1 billion, was to have received FF675 million in regional aid. Scientists point out that the remainder is almost exactly what the government is pledging towards Diamond, and that this does not take into account the cost of renting future beamlines, the additional upkeep of LURE, or travel budgets.

Scientists have demanded that Allègre reveal the details behind his decision, and particularly that he publish a report he commissioned that was favourable to the British plan.

"It seems very curious that the minister made [this] decision without having any interactions with the scientists involved," says one expert.

The protest is likely to continue for a couple of weeks. About 400 scientists work at LURE, and 1,800 visit each year to use its facilities.

Heather McCabe

\section{Obuchi vows to push university reforms in Japan}

Tokyo

A plan by the Japanese government to transform the country's 99 national universities into semi-autonomous 'agencies' moved a step closer to reality last week when Keizo Obuchi, the prime minister, promised to enforce the reform if he is re-elected head of the ruling Liberal Democratic Party (LDP).

Obuchi stressed the importance of restructuring the universities in a statement on education policy issued as part of his reelection campaign. The plans are part of a broader effort to increase administrative efficiency by turning government-run organizations into semi-autonomous bodies (see Nature 389, 897; 1997).

Koichi Kato, Obuchi's main opponent in the election and a supporter of Japanese lifescience research, also backs the agency plan as a step towards privatizing the universities. Kato has been critical of the current university system, particularly the restrictions of civil-service law which prohibit researchers from taking part in commercial activities.

Spurred on by this political pressure, the Ministry of Education, Science, Sports and

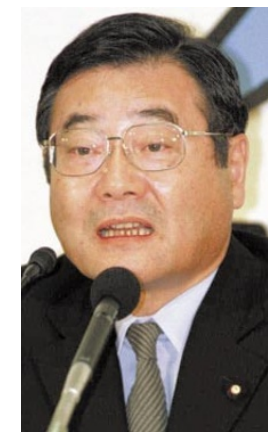

Kato: universities should be privatized.
Culture (Monbusho), which had opposed the government's reforms, has announced that it intends to approve the plan, provided that the universities are managed under a different framework from other research institutes.

Monbusho officials say the pressure to reduce the number of civil servants was now too strong for the ministry to keep resisting the plan, as national universities have more than 125,000 staff, a sizeable proportion of Japan's civil servants.

But Monbusho argues that the current agency bill, which sets targets based on cost performance, could affect the standard of research and education.

The ministry plans to ask that the bill be modified or that there should be a separate bill for universities, so their priorities would not be dictated by financial performance.
It insists that the evaluation of each agency be carried out by an independent assessment body, which Monbusho plans to set up next year (see Nature 400, 704; 1999). It wants to see performance-related targets selected by the education minister.

Monbusho's committee on university reform (see Nature 400, 703; 1999) will meet today (16 September) to finalize its proposals. Monbusho is expected to announce its final decision at a general meeting of the deans of the national universities on 20 September.

This schedule has been criticized by many as being too strongly influenced by political factors. Hirokuni Ono, head of Tokyo University's staff union, says Monbusho "shouldn't be rushing its decision because of the LDP election."

"Japan spent a long time deciding whether to privatize its railway and telecommunications sector," says Minoru Oda, former director of the Institute of Space and Astronautical Sciences and a member of the Monbusho committee. "I don't see how the government could decide the fate of the universities in such a short space of time."

Asako Saegusa 